\title{
Trachoma in schoolchildren of the city of Botucatu, Sao Paulo, Brazil: detection and health promotion of a neglected disease
}

\author{
O tracoma em escolares do município de Botucatu, \\ São Paulo, Brasil: detecção e promoção \\ de saúde em uma doença negligenciada
}

Roberta Lilian Fernandes de Sousa Meneghim ${ }^{1}$, Carlos Roberto Padovani² ${ }^{2}$ Silvana Artioli Schellini ${ }^{3}$

\begin{abstract}
Objective: The purpose of this study was to promote the teaching of trachoma and to act in the combat of this leading cause of preventable blindness. Methods: This proposal was approved by the Ministry of Health (PET Program - Health / Health Surveillance), predicting the service training of medicine and nursing graduate students and health workers, in Botucatu, Sao Paulo - Brazil, in 2010. The training covered theory and practice, which consisted of cross-sectional study, with a randomized sampling to study the prevalence of inflammatory trachoma in schoolchildren from first to 4th grades of public elementary schools, following the World Health Organization criteria (WHO) and the supervision of two certified ophthalmologists for clinical diagnosis. The data were statistically analyzed. The staff was evaluated for learning. Results: The fieldwork showed that the prevalence of trachoma in children of Botucatu in 2010 was $3.42 \%$. Compulsory notification, the communicants search, the treatment application to the affected and the follow-up as standardized happened with the active participation of staff. Conclusion: The prevalence of inflammatory trachoma in Botucatu in 2010 was $3.42 \%$. The activities developed by the participants of PET Program - Health / Health Surveillance - Trachoma allowed effective training in service, resulting in the formation of multipliers, an additional force in the fight for the elimination of trachoma as a blindness cause.
\end{abstract}

Keywords: Trachoma/prevention \& control; Trachoma/epidemiology; School health; Health education; Child;_Epidemiologic surveillance

\section{RESUMO}

Objetivo: O objetivo do presente trabalho foi promover o ensino do tracoma, assim como atuar no combate esta desta importante causa de cegueira evitável. Métodos: Esta proposta foi aprovada pelo Ministério da Saúde (Programa PET - Saúde/Vigilância em Saúde), prevendo o treinamento em serviço de alunos de graduação em Medicina e Enfermagem e agentes de saúde, no município de Botucatu, São Paulo - Brasil, no ano de 2010. O treinamento abrangeu parte teórica e prática, a qual constou de estudo transversal, por amostragem aleatorizada, para estudo da prevalência do tracoma inflamatório em escolares de $1^{\mathrm{a}}$ a $4^{\mathrm{a}}$ séries do ensino público fundamental, seguindo os critérios da Organização Mundial de Saúde (OMS) e com supervisão de dois oftalmologistas com certificação para o diagnóstico clínico. Os dados obtidos foram analisados estatisticamente. A equipe foi avaliada quanto ao aprendizado. Resultados: O trabalho de campo mostrou que a prevalência de tracoma em crianças do município de Botucatu no ano de 2010 foi de 3,42\%. A notificação compulsória, a pesquisa dos comunicantes, aplicação do tratamento para os afetados e o seguimento conforme padronizado aconteceu com a participação ativa da equipe. Conclusão: A prevalência do tracoma inflamatório em Botucatu no ano de 2010 foi de 3,42\%. As atividades desenvolvidas pelos participantes do Programa PET - Saúde/Vigilância em Saúde - Tracoma permitiu treinamento em serviço efetivo, resultando na formação de multiplicadores, uma força adicional na luta pela eliminação do tracoma como causa de cegueira.

Descritores: Tracoma/prevenção \& controle; Tracoma/epidemiologia; Saúde escolar; Educação em Saúde; Criança; Vigilância Epidemiológica; Prevalência

\footnotetext{
${ }^{1}$ Department of Ophthalmology, Otorhinolaryngology and Head and Neck Surgery, Faculdade de Medicina de Botucatu, Universidade Estadual Paulista "Júlio de Mesquita Filho, Botucatu, SP, Brazil.

2 Department of Biostatistics at Instituto de Biociências, Universidade Estadual Paulista "Júlio de Mesquita Filho, Botucatu, SP, Brazil.

${ }^{3}$ Department of Ophthalmology, Otorhinolaryngology and Head and Neck Surgery, Faculdade de Medicina de Botucatu, Universidade Estadual Paulista "Júlio de Mesquita Filho", Botucatu, SP, Brazil.

Institution where the study was carried out: Faculdade de Medicina de Botucatu - Universidade Estadual Paulista "Júlio de Mesquita Filho", Botucatu, SP, Brazil.

The authors declare no conflicts of interests.

Received for publication 04/07/2016 - Accepted for publication 09/07/2016.
} 


\section{INTRODUCTION}

$\mathbf{T}$ he World Health Organization (WHO) considers trachoma as a neglected disease that needs to be fought ${ }^{(1)}$, and measures must be taken to ensure that the fight is effective.

Brazil is considered an endemic country for trachoma, and is among those who pledged to eliminate trachoma as a cause of blindness by the year $2015^{(1)}$. According to the resolution of the World Health Assembly of $1998^{(2,3)}$, the WHO aims to eliminate trachoma as a cause of blindness by the year 2020. To achieve this goal, it is essential to use the SAFE strategy ${ }^{(1,4)}$, and adopt the surveillance and control practices, knowledge of the epidemiological situation of the affected areas, access to diagnosis and treatment of trachoma, and educational actions for prevention ${ }^{(5)}$. In this sense, the Ministry of Health has approved a project related to in-service training within the call for bidding PET-Health/Health Surveillance, a proposal made to act in trachoma with the participation of graduate students in Medicine and Nursing.

Botucatu was home to one of 36 trachoma dispensaries in the State of São Paulo in the 40s of the last century, to be the place of concentration of population of Italian immigrants who were carrying the disease ${ }^{(6)}$. So, no doubt this city could be considered for the proposal, mainly due to these historical background, and also due to indicators obtained in 1991, when there was a prevalence of $11.6 \%$ of disease in the city ${ }^{(7)}$, followed by $29 \%$ in $2005^{(8)}$, showing that the disease is still among us.

So the main goal of this action was to promote the dissemination of knowledge about the disease to young students and community health agents, alerting the population and also using the methodology of active search of trachoma in schoolchildren.

\section{Methods}

The present study was approved by the Research Ethics Committee, and was part of the Labor Education Program for Health (PET) Health/Health Surveillance, of the Ministry of health (Ministerial Ordinance 421 of 2010), which aims at the insertion of relevant issues for the Brazilian Public Health in teaching scenarios.

The team was composed by two ophthalmologists who have trained undergraduates from Faculdade de Medicina de Botucatu at Universidade Estadual de São Paulo (UNESP), four students being from the graduation course in Medicine who attended the third period (second year), four students from the graduation course in Nursing who attended the third period (second year), and two community agents of the city of Botucatu, all participating members and fellows of the PET - Health/Health Surveillance - Trachoma.

Activities started with the team training, with classes and seminars about the disease, involving issues such as eye and annexes anatomy, transmission of the disease, treatment and control methods, research methods, history, and spread of the disease in the country and the world, intervention targets for trachoma control, forms of diagnosis, surgical treatment of trichiasis/entropion, disclosure of the SAFE strategy, as well as classes on writing scientific papers. The teaching material was presented in classes, films, discussion of scientific papers and lectures with experts on data geoprocessing, vector action and ways to capture them. Active teaching methodologies were also used, like practical lessons about the examination for the detection, diagnosis and transmission of the disease. Students were encouraged to develop a folder with explanations about the disease, its transmission, treatment and prevention. They also created traps for flies that were used to capture possible vectors of trachoma transmitters. This phase lasted three months, with skills assessed by written test on specific knowledge of trachoma and seminars given by students.

Then there was the field work described below.

\section{Field research}

All stages of field research were discussed and had the active participation of students and agents of the health program PET under the supervision of two certified ophthalmologists.

To determine the prevalence of trachoma in Botucatu, a cross-sectional study was carried out by random sampling, evaluating schoolchildren from first to fourth grades of elementary school of all the 18 public schools of Botucatu, São Paulo-Brazil, in order to detect cases of trachoma.

According to the Municipal Department of Education, in 2010, 4969 students attended the first to fourth grades of elementary school in the city. Following the sample calculation that took into account the number of students and the historical prevalence of inflammatory trachoma in the city, which was $2.9 \%$ in a previous study ${ }^{(8)}$, and considering the $95 \%$ confidence interval, the maximum estimation error of $2 \%$ and the sampling error of $10 \%$, the need to test 3568 children was reached.

The determination of students to be examined followed the randomization established by raffle of classes in each of the municipal schools, until the estimated sample size was reached. The class was considered the primary sample unit, and all students belonging to the same were examined.

First, there was a clarification meeting to explain the importance of the campaign to all principals and teachers of schools, a moment also used to disseminate knowledge about trachoma.

An informed consent was addressed to the parents of children belonging to the classes selected by the school principals. Children who had the term signed were examined following the diagnostic standard advocated by the WHO, based on the clinical diagnosis made using 2.5 times increase magnifiers and handheld lantern, by examining the upper tarsal conjunctiva after eyelid eversion ${ }^{(4)}$. The presence of five or more follicles equal to or greater than $0.5 \mathrm{~mm}$ or the thickening of the upper tarsal conjunctiva able to obscure half of the deep tarsal vessels, data charactering the follicular and intense forms of inflammatory trachoma were searched, as well as the presence of tarsal scars ${ }^{(9)}$. The tests were conducted by two ophthalmologists duly qualified to detect the disease, along with students and health agents, and all tests were carried out in a week.

The kids diagnosed as trachoma patients were invited along with their families to be examined (communicant) and for the administration of antibiotics for treatment. A clarification lecture about the disease was made for the parents of the students. Then azithromycin (Germed, Campinas, Brazil) was administered in a single dose, following the recommendations of the Ministry of Health: $20 \mathrm{mg} / \mathrm{kg}$ of body weight for children, or $1 \mathrm{~g}$ for people over $50 \mathrm{~kg}^{(5)}$. The monitoring of cases was also made following the principles of the WHO to do so.

The data was statistically analyzed, and the prevalence and standard error estimated by the range of $95 \%$ confidence interval for the proportion of occurrence. 


\section{Results}

\section{Results of the training of students}

In order to participate in the Program PET - Health/Health Surveillance, the students were selected by means of a written exam consisting of an essay demonstrating why they would like to participate in the program. Students should be enrolled and attending the second year of graduation in Medicine, first or second year of graduation in Nursing, second year of Life Sciences or second year of biomedical Sciences ${ }^{(10)}$ at Universidade Estadual Paulista (UNESP) - Campus of Botucatu, SP.

The group was heterogeneous, with participation of Nursing and Medicine students, and whose knowledge of trachoma did not exist previously.

The class participation was as planned and intense. The first classes were taught by two ophthalmologists. Classes involving specific subjects of non-medical areas and which would be important for the implementation of the project, such as data geoprocessing, collection of possible vectors, and writing of scientific texts were taught by professionals in the biological area and by a librarian, confirming the interdisciplinarity of the project. Other contents were presented as seminars, also used as a method of evaluation of the participating students.

There was greater difficulty in retaining knowledge on three main points: 1) clinical diagnosis of the disease, with the differentiation of forms of inflammatory trachoma (Follicular Trachoma and Intense Trachoma);2) with regard to research of the disease, particularly regarding Rapid Assessment due to the complexity of the statistical calculations to determine samples in this form of research; 3) definition of the criteria for medical discharge and discharge with healing of the children after treatment.

It was easy for the students to understand the meaning and the importance of the disease, prevention methods and ways of acting in the means of transmission, in order to decrease the prevalence of trachoma. This fact was noted by the ease they had in making a well-structured folder with clear and accurate information, showing that they were able to assimilate the knowledge they gained in the program.

The entire team of PET - Health/Health Surveillance Trachoma participated actively in the design and implementation of field work, being trained in such a way that fellows and health agents could be multipliers. Despite not being legally qualified to the test, future professionals could follow the embodiment of the ocular assessment, noting all the positive cases found in the field work, as well as work in search of communicants, notification of positive cases and the institution of treatment.

\section{Results of the field work}

Validation of clinical diagnosis was made by trained ophthalmologists, since it is possible to have people certified in respected courses to work in the field.

Of the total sampled, 3238 children were examined $(90.75 \%$ of the desired sample) in the period from October to November 2010. The reduction of the sample was due to some parents not agreeing to take part in the study, the refusal of some children to be examined, the absence of students on the day of the exam, or administrative reasons in one of the schools. Thus, the loss was of $9.25 \%$ of the initial sample.

The detected cases of inflammatory trachoma were 111, with 108 being of follicular trachoma patients and three cases of intense trachoma. No child presented cicatricial trachoma. The prevalence of trachoma in the city of Botucatu in children from first to forth grades was $3.42 \%$. The distribution of cases between schools showed variation between $0.44 \%$ and $8.87 \%$ (Table 1 ).

It is important to note that, at the same time the active search for cases of trachoma in the community was performed, educational activities and health promotion have been put into practice.

In addition to the graduation students in Medicine and Nursing and the health agents, the teachers of the participating schools as well as the population were also aware of the need to fight the disease as they experienced transmission, and measures should be taken to prevent the spread of the disease.

Table 1

Distribution of the number of children examined and the number of cases of Trachoma found in the participating schools

\begin{tabular}{lccc}
\hline \multicolumn{1}{c}{ School } & $\mathbf{N}^{\mathbf{0}}$ of children & No of cases \\
\hline EMEF Angelino de Oliveira & 283 & 04 & 03 \\
REFER Américo Virgínio dos Santos & 94 & 03 & 3.41 \\
EMEF Francisco Guedelha & 97 & 07 & 3.09 \\
EMEF Antenor Serra & 256 & 03 & 2.73 \\
EMEF Cardoso de Almeida & 239 & 09 & 1.25 \\
EMEF João Maria de Araújo Junior & 191 & 03 & 4.71 \\
EMEF João Queiroz Marques & 222 & 15 & 1.35 \\
EMEF Jonas Alves de Araújo & 169 & 05 & 8.87 \\
EMEF José Antônio Sartori & 251 & 05 & 1.99 \\
EMEF Luiz Carlos Aranha Pacheco & 118 & 01 & 11 \\
EMEF Luiz Tácito Virgínio dos Santos & 226 & 18 \\
EMEF Prof Martinho Nogueira & 274 & 13 \\
EMEF Prof Nair Amaral & 266 & 0.23 \\
EMEF Prof Paulo Guimarães & 215 & 0.44 \\
EMEF Rafael de Moura Campos & 164 & 02 \\
EMEFEI Raul Torres & 32 & 04 \\
EMEF Raymundo Cintra & 141 & $\mathbf{1 1 1 1}$ \\
TOTAL & $\mathbf{3 2 3 8}$ & 4.01 \\
\hline
\end{tabular}

EMEF - Escola Municipal de Ensino Fundamental; EMEFEI - Escola Municipal de Ensino Fundamental e Ensino Infantil 


\section{DisCUSSION}

Trachoma is an ancient disease that ceased to be taught and researched in Brazil in the 70s and 80s because the disease was believed to be extinguished as a cause of blindness in the country. However, due to the focus detected in Bebedouro, São Paulo, Brazil ${ }^{(11)}$, the disease reemerged with need to act also in education and health promotion as ways to achieve the elimination of the problem ${ }^{(12)}$.

Health education is not only a way to disseminate knowledge on health, but to promote the individual with the ability to be motivated, confident and skilled to improve their health and that of their peers. The focus of health education is, therefore, to make the individual aware and able to meet the social, economic and environmental determinants of the problems to be fought ${ }^{(12)}$.

The promotion of health, in turn, is a combination of activities of health education and adoption of policies capable of enabling the individual to improve and increase their control over their health. Is nothing more than the process of implementation of health education ${ }^{(12)}$. The concept arose in the 70 as a response to contemporary health challenges ${ }^{(13)}$.

Due to trachoma being considered extinguished for about 20 years, in order to reach actual elimination of the disease as a cause of blindness we need to teach, understand and communicate information, engaging with the demands in different contexts, trying to show in practice all stages of the disease and its combat ${ }^{(12)}$.

Thus, health education, health promotion and prevention go together in the development of the individual to reach a state of full welfare. In 2010, the Brazilian federal government created the Labor Education Program for Health (PET Health/Health surveillance), which aims to promote tutorial learning groups in strategic areas for the Single Health System (SUS) ${ }^{(14)}$. The program was created jointly by the Ministries of Health and Education, and presupposes education through labor as a means of training health professionals and the initiate them at work. The present study was carried out within these principles.

The goals of the program include: encourage the training of professionals and teachers with technical, scientific, technological and academic skills, develop academic activities through tutorial learning groups, contribute to the development of health professionals targeted to the needs and health policies of the country, and promote the articulation of teaching-servicecommunity in health ${ }^{(14)}$, which was exactly what we have developed with our group.

Considering the concepts of health, health education, prevention, and the fact that trachoma is among the neglected diseases in the world, the project developed in Botucatu meets the needs and expectations of the Ministry of Health with regard to the fight against neglected diseases ${ }^{(5)}$.

Moreover, it goes along with the objectives of the PET program and the health education principles established by the WHO, to the extent that the graduate students were trained and qualified to diagnose trachoma, to conduct cases according to the criteria of the WHO, making interventions in the community by researching the prevalence of trachoma and promoting health through lectures and notification of the cases found. Undoubtedly, participants had the opportunity to experience all the important issues of the disease, and they can act as replicators in future studies or during their professional lives.
Botucatu has a long relation with trachoma. In 1944, the State of São Paulo was divided into seven incidence zones of trachoma, and Botucatu was part of the third zone, with a prevalence of active trachoma of $10.1 \%^{(6)}$. In 1982, with the outbreak of trachoma in Bebedouro, three cases of trachoma were reported in Botucatu, which gave raise to a search that ended up determining a prevalence of $11.6 \%$ of trachoma in $1992^{(7)}$.

From this moment on, the research continued in the city, with a new survey in 2005 showing a prevalence of $2.9 \%$. The drop in prevalence over the years probably was due to the control measures implemented after the previous research and the improvement of the health conditions of the population ${ }^{(8)}$. Thus, the study of the disease in the city is also important for the encouragement of the community to the adoption of measures that will contribute to the elimination of trachoma as a cause of blindness.

The present research reveals a prevalence of $3.42 \%$ of inflammatory trachoma. The measures taken should reflect positively for the decline of these numbers. The research also involved the analysis of the areas of the city that were most affected, information that is also important for new investigations.

Health education is critical to the development of health in the population. The development of projects to encourage young health professionals to work in the community to promote health is key to achieving physical, mental and social welfare as desired. The current prevalence of trachoma, as found in the year $2005^{(8)}$, was low and within the limits accepted by the $\mathrm{WHO}^{(4)}$. However, it is important to note that guidance measures for the population are extremely needed to achieve the elimination of the disease as a cause of blindness in the city.

\section{Conclusion}

Participation in the Program PET Health/Health Surveillance - Trachoma was a way to instrument young health professionals to act correctly in fighting the disease, as well as the awareness of the population about the disease and its transmission. This way, the authors consider that the activities have influenced positively so that trachoma can be eliminated as a cause of blindness in Botucatu or in other locations where participants will work this way.

\section{ACKNOWLEDGEMENTS}

To the participants of the Labor Education Program for Health - PET, Health Surveillance - Trachoma, nurse Nádia Maria Fattori Alves, of CRIE - UNESP, and nurse Rita Maria Lourenção Simão Geraldo, of Secretaria Municipal de Saúde de Botucatu; to the students of the Medicine course Wesley Rodrigues Venturin, Jonas Atique Sawazaki and Ligia Mitie Ikeda; to the students of the Nursing course Aglécia Moda Vitoriano, Rafaela Ribeiro, Ana Soraya Andrade and Francielle Janaína de Souza.

\section{RefEReNCES}

1. Savioli L, Daumerie D, Crompton DW, Peters P. Working to overcome the global impact of neglected tropical diseases - First WHO report on neglected tropical diseases. Genebra: WHO; 2010. 
2. World Health Organization (WHO). Report of the first meeting of the WHO alliance for the global elimination of trachoma. Genebra: WHO; 1997. 35 p.

3. Mariotti SP, Prüss A. The SAFE strategy: Preventing Trachoma A guide for environmental sanitation and improved hygiene. Genebra: WHO; 2001. 36 p.

4. World Health Organization (WHO). Trachoma control: a guide for programme managers. Switzerland: World Health Organization, London School of Hygiene \& Tropical Medicine, and International Trachoma Initiative; 2006. 53 p.

5. Brasil. Ministério da Saúde. Manual de vigilância do tracoma e sua eliminação como causa de cegueira. Brasília: Secretaria de Vigilância em Saúde. Departamento de Vigilância das Doenças Transmissíveis; 2014. 52 p.

6. Toledo O. O combate ao tracoma no Estado de São Paulo. São Paulo: Síntese; 1944. [apud Medina NH, Gattás VL, Anjos GL, Montuori C, Gentil RM. Prevalência de tracoma em pré-escolares e escolares em Botucatu, Estado de São Paulo, Brasil, 1992. Cad Saúde Pública. 2002;18(6):1537-42].

7. Medina NH, Gattás VL, Anjos GL, Montuori C, Gentil RM. Prevalência de tracoma em pré-escolares e escolares em Botucatu, Estado de São Paulo, Brasil, 1992. Cad Saúde Pública. 2002;18(6):1537-42.

8. Schellini SA, Lavezzo MM, Ferraz LB, Olbrich Neto J, Medina NH, Padovani CR. Prevalência e localização especial dos casos de tracoma detectados em escolares de Botucatu, São Paulo Brasil. Arq Bras Oftalmol. 2010;73(4):358-62.

9. Thylefors B, Dawson CR, Jones BR, West SK, Taylor HR. A simple system for the assessment of trachoma and its complications. Bull World Health Org. 1987;65(4):477-83.
10. São Paulo, Estado (Diário Oficial) [Interne]. Poder executivo, Caderno 1, 16/06/2010. [citado 2015 Jan 18]. Disponível em: http:/ /www.jusbrasil.com.br/diarios/5675803/pg-50-executivo-caderno1-diario-oficial-do-estado-de-sao-paulo-dosp-de-16-06-2010.

11. Luna EJ, Medina NH, Oliveira MB, Barros OM, Vranjac A, Melles $\mathrm{HH}$, et al. Epidemiology of trachoma in Bebedouro State of São Paulo, Brazil: prevalence and risk factors. Int J Epidemiol. 1992;21(1):169-77.

12. World Health Organization (WHO). Health education: theoretical concepts, effective strategies and core competencies - A foundation document $t$ guide capacity development of health educators. Genebra: WHO; 2012. 82p.

13. Carvalho SR. Os múltiplos sentidos da categoria "empowerment" no projeto de Promoção à Saúde. Cad Saúde Pública. 2004;20(4):1088-95.

14. Brasil. Ministério da Saúde e Ministério da Educação [Internet]. Portaria Interministerial $n^{\circ} 421$, de 03 de março de 2010. [citado 2015 Jan 17]. Disponível em: http://www.brasilsus.com.br/ legislacoes/inter-ministerial/103143-421.html.

\section{Corresponding Author:}

Roberta Lilian Fernandes de Sousa Meneghim

Rua Carlos Guadanini, 1775 - Jardim Flamboyant - Botucatu São Paulo

ZIP Code 18610-120Phone/ Fax: 1438116256

E-mail: rlfsousa@yahoo.com.br 